\title{
Technology-Based Learning Innovation In the Pandemic Covid-19
}

\author{
Hidayati Azkiya $^{1)}$, Hermawati Syarif ${ }^{2)}$ \\ ${ }^{1)}$ Universitas Bung Hatta, ${ }^{2)}$ Universitas Negeri Padang \\ email: hidayatiazkiya@bunghatta.ac.id ${ }^{1}$, hermawati_sy@yahoo.com ${ }^{2}$
}

\begin{abstract}
This article aims to analyze and describe technology-based learning innovations during the pandemic Covid-19. Learning innovations are expected to provide solutions and prevention of Covid-19. The research method used is qualitative research with a literature review method. Data collection was carried out by tracing various sources in the form of government documents, mass media, and relevant research results previously analyzed using policy research and supported by the results of interviews with several elementary school students. Data analysis using Content Analysis. The results of this study indicate that government policies in tackling the spread of the corona virus (Covid-19) have an impact on the emergence of new concepts related to technology-based learning innovations that can be applied. These learning innovations include Learning from Home: Collaboration between schools and parents, learning as an opportunity as well as a challenge, and the innovation of the Blended Learning learning model. It is hoped that these innovations can provide optimal results and can increase collaboration between parents, teachers, and the government in order to realize quality education and be able to compete globally. Technology-based learning innovation is expected not only to take place during the pandemic Covid-19, but can be applied after Covid-19 ends for more advanced and quality education.
\end{abstract}

Keywords: Innovation, Learning, Technology, Corona Virus (Covid-19)

\section{Introduction}

At the beginning of the outbreak of the Corona Virus or Covid-19 (Corona Virus Disease-19) originating from Wuhan, China (Shi, et al., 2020) and reported at the end of 2019 it had an impact on various aspects of human life. This virus is developing very quickly in various countries and it is difficult to detect people who have been exposed because the incubation period of this virus is approximately 14 days which can result in an increase in the number of infected victims. People who have contracted Covid-19 are usually characterized by several symptoms such as cough, respiratory problems, sore throat, and fever with a temperature above 38 o C (Rina, 2020). However, there are also some cases that do not show symptoms. This is very worrying. The number of cases of patients exposed to Covid-19 is increasing day by day, there are even hundreds of thousands of people exposed and tens of thousands of people dying worldwide. Therefore, on March 11, 2020 WHO (World Health Organization) decided/determined this disease outbreak as a pandemic (Putri, 2020). The spread of Covid-19 can be through fluids that come out of the human body and direct contact such as physical contact. For this reason, community social activities are considered the highest risk in the spread of Covid-19. Thus, this pandemic becomes a challenge for every country, including Indonesia to determine a solution so that the number of victims does not increase continuously.

As for the spread of Covid-19 in Indonesia, since President Joko Widodo announced the first case on March 2 to June 17, 2020, 41,431 people were infected, 16,243 people recovered, and 2,276 people died due to the Covid-19 pandemic spread across 34 provinces (Purnamasari, 2020). In this regard, the 
Indonesian government made a policy as an effort to prevent this by giving an appeal to the public to always maintain physical distance, avoid all forms of activity in the form of crowds and always maintain cleanliness of course. Another policy taken by the government is that teaching and learning activities, work, and worship are carried out at home (Darmalaksana, 2020).

The consequences of the pandemic have caused very drastic and sudden changes in every aspect of life, including education. At the level of education ranging from elementary school to college as if "forced" to adapt to the environment (Ariyandi, 2020), all teachers are required to carry out distance/online learning activities (Atsani, 2020) which is set on March 24, 2020 as stated in the Circular of the Minister of Education and Culture as an effort to decide the spread of Covid-19 in Indonesia (Mendikbud, 2020).

Based on this description, the changes that occur are not easily accepted by some parties, but under current conditions, only technology can bridge so that the teaching and learning process or knowledge transfer continues. Therefore, all parties must be able to adapt to online learning. Online learning is actually not a new thing that has emerged during the Covid-19 pandemic in certain countries which has become a demand for the world of education since a few years ago (He, et al., 2014), where face-to-face learning is considered traditional learning, with Thus, better learning facilities are needed by utilizing information technology (Panigrahi, et al., 2018). So that by carrying out online learning will create a modern learning environment (Huda, et al., 2018). In addition, online learning is needed in learning in the 4.0 revolution era (Sadikin \& Hamidah, 2020).

Based on this, before Covid-19 entered Indonesia, the implementation of learning that was applied was still traditional learning. Although there are certain schools that have implemented learning through IT, especially at the elementary school level, traditional learning is still the main priority. However, there are not a few schools that carry out offline learning, especially for schools located in villages and seem to be left behind. This is due to the limited availability of infrastructure, limited ability of teachers to apply technology, uneven facilities owned by students/parents, difficulty in obtaining internet access due to geographical location and other considerations that may occur during the implementation of online learning.

However, when the Covid-19 pandemic hit Indonesia, the situation changed drastically, as if there was coercion in this case, where the implementation of learning which was originally applied offline/traditionally, has now drastically changed to online/modern learning. The obstacles as mentioned above are not seen as an obstacle anymore, but are seen as a challenge that must be faced for every element that plays a role in the field of education. This is the only way that education can still be delivered to students. Although it is not easy, this is the only thing that can bridge the implementation of education in the midst of the current epidemic. Therefore, through this article the author wants to examine more deeply related to technology-based learning innovations contained in the implementation of learning during the Covid-19 pandemic.

Referring to this goal, innovation arises because of a situation that makes a person solve a problem in the surrounding environment (Sanjaya, 2006). Innovation is also defined as a new idea that is felt by various parties, either individually or in groups. This idea can be seen from what information technology produces (Sururi, 2017). The idea in question can be in the form of practices or products that are applied as problem solving with the aim of improving certain conditions that occur in society (Nawangsari, 2010).

The characteristics of innovation are as follows: (a) there is a relative advantage, meaning that something is said to be an innovation if it can be profitable for people who receive it, the more profitable the innovation is, the faster it will spread in the community; (b) compatible, namely the suitability of the innovation with values, this is related to the experience and also the needs of the people who accept the innovation; (c) complexity, namely the level of difficulty in understanding and using the innovation; (d) triability, the existing innovation can be accepted or not by the recipient; and (e) observability, the existing innovations can really know the benefits (Kadi \& Awwaliyah, 2017). Some of the goals of educational innovation in Indonesia are: (a) to catch up with various advances in science and technology; 
(b) strive to provide education equally and fairly; and (c) reforming the Indonesian education system to be more effective, efficient, and producing quality output in accordance with the needs of the community in the future, and so on (Kusnandi, 2017).

\section{Methods}

This study uses a qualitative approach with literature study analysis techniques related to technologybased learning innovations during the Covid-19 pandemic. Furthermore, data collection in this study was carried out by tracing various sources in the form of government documents, mass media, and relevant research results previously analyzed using policy research (Anggara, 2015) and supported by the results of interviews with several elementary school students. Data analysis was carried out using Content Analysis. Content Analysis is a method used to obtain information from documents in the form of recordings, images, sounds, writings and others objectively and systematically (Arikunto, 2016).

\section{Results and Discussion}

The Covid-19 pandemic has an impact on all aspects of life as described above, including the field of education. Education is defined as a means to shape humans into individuals who are able to face the challenges of the times, so education must also be ready to respond to all forms of changing times itself. So it can be said that innovation in education is a must. Therefore, the authors analyze and describe several innovations applied in learning during the Covid-19 pandemic.

\section{Learning from Home: Collaboration Between Schools and Parents}

Learning from Home is motivated by Covid-19. Previously, learning was carried out face-to-face in the classroom. However, during the COVID-19 pandemic, face-to-face learning which had become a tradition/culture of the Indonesian people turned into online learning (online) using technology (Sudarsana, et al., 2020). Teachers must be able to ensure that even though students study from home, students continue to study simultaneously even though they are in different places. This online learning system is implemented through technology, namely cellphones through the Whatsapp group (WAG) application, telegram, Zoom application, and other online services. Carrying out online teaching and learning activities is not an easy thing to do, especially for elementary school students. There are various difficulties experienced by teachers and students. The difficulties experienced by students based on the results of interviews that the author conducted with students in grades V and II related to how they felt during online learning, both stated that they did not fully understand the learning materials contained in the textbooks because the teacher did not explain the subject matter as implemented. in the classroom. During the implementation of online learning, the teacher only gives a number of questions for students to work on with the help of their respective parents. But sometimes, their parents experience a number of obstacles such as not understanding how to do the problem, especially in Mathematics and English. Then after the assignment is completed, the assignment is photographed and then sent via WAG (Whatsapp Group) which is connected to the student's guardian (Interview Aska (V) and Azam (II).

This kind of learning is considered ineffective and there are various obstacles experienced by parents whose primary education only they do not graduate / pass. In addition, learning like this is also often boring for students, many of whom complain and hope that they can go to school as usual. In this regard, the transformation of learning from face to face to online also appears various obstacles that must be passed by teachers or guardians of students. Many parents complain because of the limited technological facilities they have, such as smartphones, laptops and so on (Miarso, 2007). Especially for parents whose children are still in elementary school.

In addition to the limited facilities they have, parents also find it difficult to guide their children to study at home, have difficulty accessing the internet, either because of the economy or geographical location. Similar to student guardians, teachers also have complaints about the implementation of online 
learning, in which the teacher admits that it is difficult to adapt to existing technology so that students remain active and enthusiastic in participating in learning. In this regard, the Minister of Education and Culture (Mendikbud) took the initiative to organize a home study program through Educational TV (Kemendikbud, 2020) since April 13, 2020 (Atsani, 2020) aimed at students from all paths, levels, and types of education, education practitioners and also the community (Kemendikbud, 2020). Online learning during the Covid-19 pandemic was carried out as a response to the Physical Distancing policy. In this case, teachers, parents, and the government are expected to work together so that education in Indonesia can continue to be carried out even though in the midst of a disease outbreak that is sweeping the world today. In addition to the limited facilities they have, parents also have difficulty guiding their children to study at home, experiencing difficulties in access the internet, either because of the economy or geographical location. Similar to student guardians, teachers also have complaints about the implementation of online learning, in which the teacher admits that it is difficult to adapt to existing technology so that students remain active and enthusiastic in participating in learning. In this regard, the Minister of Education and Culture (Mendikbud) took the initiative to organize a home study program through Educational TV (Kemendikbud, 2020) since April 13, 2020 (Atsani, 2020) aimed at students from all paths, levels, and types of education, education practitioners and also the community (Kemendikbud, 2020). Online learning during the Covid-19 pandemic was carried out as a response to the Physical Distancing policy. In this case, teachers, parents, and the government are expected to cooperate with each other so that education in Indonesia can continue to be carried out even in the midst of a disease outbreak that is sweeping the world today.

Parents have a very important role and have a great influence on the success or failure of online learning (Valeza, 2017), because the ability of parents to guide their children to learn is one of the most powerful strategies. Therefore, parents can be said to be the key to success in implementing learning from home. The collaboration between teachers and parents as conveyed by Evania Yafie includes the school holding a webinar at the beginning of the semester regarding learning strategies that will be carried out at home during the Covid-19 period. On this occasion, the school provided training to parents on the implementation of collaborative learning. Furthermore, the school and parents make an agreement on each role as a form of cooperation carried out between the two parties, in this case the teacher and parents.

In this case, the school acts as a designer, facilitator, supervisor and also evaluator of learning, while parents act as implementers of learning activities/teachers. In this regard, there are at least four roles of parents in the implementation of learning from home, namely as teachers in charge of guiding their children at home; as a facilitator who provides all online learning needs, a motivator who always provides enthusiasm for learning; and also as an influence (Winingsih, 2020). However, as we know that many parents are busy with their work, especially for those who are domiciled in urban areas, so that the education of their children is entirely left to the teachers at school. Since the learning policy has been implemented online, the culture has begun to change slightly. Inevitably, parents must accompany their children in the learning process. In addition, online learning can also strengthen the relationship between parents and their children and parents know for sure the extent of their child's development in learning (Haerudin, et al., 2020). However, in carrying out the role as a parent is not easy for some parties, this is because many parents with low educational backgrounds find it difficult to guide their children to complete the tasks given by the teacher, besides that not a few parents who do not have adequate facilities to carry out their duties as parents. support the implementation of online learning.

As the implementation of learning in the classroom which only focuses on the knowledge aspect, online learning is the same, parents do not have to only focus on certain aspects (Sudarsana, et al., 2020), but all aspects of learning which consist of aspects of attitude, knowledge and skills. Skills. Therefore, it is necessary to innovate in carrying out learning, not only by teachers, but parents also have to innovate learning during the Covid-19 pandemic as an effort to overcome learning at home so that students are not bored and stressed because of the transformation of learning and must adapt to new conditions (Melhuish, 
et al., 2008). An innovation that can be applied by parents during learning from home is to improve aspects of students' attitudes and skills. In terms of skills, for example, parents can invite their children to do educational activities such as cooking, gardening, learning while playing and so on. As for the attitude aspect, parents can teach their children about religious (religious) values gradually starting from the simplest things such as praying, sharing, not disturbing others, and so on.

The innovations that must be carried out by teachers are by utilizing various technologies that can be used to support the implementation process in the form of models, methods, and learning media that are prepared as well as possible so that distance learning that is carried out online can run effectively. In addition, students must also be able to adapt to current conditions in implementing technology-based learning, so that in the future students are able to compete globally and take advantage of the various sophistications of increasingly advanced science and technology.

\section{Online Learning is Both an Opportunity and a Challenge}

Quality education is synonymous with learning that is able to provide space as well as encouragement to students to continue to express, and appreciate learning needs according to their talents, interests in growth and development as well as the environmental conditions of the students themselves. The use of technology as a medium in learning during Covid19 is one way for students to keep learning (Syarifudin, 2020), the use of technology as a learning medium requires teachers and students to move in a more advanced direction (Sudarsana et al., 2020). On the other hand, the use of technology in the implementation of teaching and learning activities is very important and useful to welcome more effective education in the future. In the development of technology in this era, it is hoped that teachers can use it as an opportunity to understand how to manage digital content well, especially for teachers who do not understand technology at all due to the pattern of adaptation that seems so fast and sudden. In addition, teachers are required to be able to take advantage of technology as an opportunity in developing education, both in terms of models, media, strategies, as well as evaluation and assessment of learning.

\section{Learning Models During the Covid-19 Pandemic}

The learning model is defined as a picture/pattern used during the implementation of the learning that will take place (Yanti, et al., 2019). Another opinion states that the learning model is a framework of systematic procedures to gain learning experiences in achieving certain goals (Al-Tabany, 2017 ). In this regard, Permendibud number 65 of 2013 explains the standards for primary and secondary education processes that: first, to achieve the learning process as stipulated in the 2013 curriculum, it is necessary to apply a scientific approach and adopt a thematic learning model, second, integrated thematic both between lessons. Or in subjects applied discovery/inquiry-based learning, and third, the teacher encourages students to produce works (Mendikbud, 2013).

The global outbreak of COVID-19 has accelerated the use and acceptance of the need for digital learning. Nevertheless, the traditional learning model in this case face-to-face is still very important to implement, especially for practical activities in the laboratory such as learning related to learning, one of which is. In the future, online assessments will be questioned regarding matters relating to validity and fairness. In this regard, the problem of plagiarism and self-responsibility in education and learning must be applied because future education emphasizes more on content than learning methods (Istiningsih, 2020). One of the models that teachers can apply during the Covid-19 pandemic is Blended Learning. Blended learning cannot be separated from e-learning learning which acts as an umbrella/foundation in carrying out online learning or we often hear the term online. The implementation of online learning cannot be separated from the help of technology and communication. E-learning used in the design of blended learning systems can be interpreted as a general and broad thing that discusses the use of various electronic technologies to deliver learning (Chaeruman, 2017). In addition, this learning is also designed to create an optimal learning experience. Electronic technology in question can be in the form of 
computers, smartphones, television, internet, and so on. The use of electronic technology to create learning experiences is seen as a series in its implementation. In this regard, Rashty (cited in Chaeruman, 2017) clarifies the e-learning series in three categories consisting of adjunct, mixed/blended, and fully online (Chaeruman, 2017).

a. Adjunct, in this category learning is carried out face-to-face and assisted by an online delivery system in addition, for example, to assist learning in class, the teacher assigns students/students to search for certain information via the internet, by utilizing various technologies such as LCD projectors and so on. . In this category, online learning is only used as an addition to the learning process.

b. Mixed/blended, in this category learning is carried out using online and face-to-face systems as an inseparable part and is a unified whole.

c. Fully online, in the last category, interactions in the implementation of learning are carried out online. In this category there is no face to face at all, for example learning materials that are linked via hyperlinks such as images and text.

Of the three categories, it can be interpreted that blended learning is part of e-learning that is designed, developed, and implemented in order to create a learning experience in order to achieve the learning objectives as determined. Blended Learning can be defined as learning that combines online and face-to-face learning (Widaningsih, 2019) at the same time, the shortcomings of face-to-face learning can be integrated with the advantages of online learning with a view to supporting maximum learning (Chaeruman, 2017). In addition, blended learning refers to the combination of different learning environments. Blended learning provides teachers and students with a potential environment to carry out learning effectively (Yaumi, 2018). In carrying out blended learning, there are important things that must be understood first with regard to learning settings, namely synchronous (learning in class/face-to-face) and asynchronous (learning outside class/online).

What is meant by learning setting is a condition and situation where learning activities can take place. The explanation is as follows:

a. Direct Sync; The first picture explains that in direct learning, students can learn at the same time and place. As well as learning that is carried out in the classroom face to face, such as lectures, discussions and so on.

b. Virtual Sync; the second picture shows that learning between students and teachers is carried out at the same time, but in different places from one another. Independent activities using online learning. Students can learn anytime and anywhere according to their respective conditions and learning speed. The learning activities in this picture include reading, listening, watching, and simulating virtual synchronous learning that occurs through the help of synchronous technology, such as video conference, audio conference and webinars.

c. Self Asynchronous; In this picture, learning is carried out by utilizing various digital materials that are in accordance with the object of study.

d. Asynchronous Collaborative; then in the last picture, the learning process is carried out by involving more than one person between students and students or someone who is a presenter. Learning activities at this stage are facilitated by discussion forums, assignments and so on.

\section{Conclusion}

Policy and innovation are two things that are interrelated and cannot be separated from each other. This is because innovation will provide useful new knowledge, while policy is a concept, guideline, and method that will strengthen the innovation. Learning innovation efforts carried out by the government with the aim of preventing the spread of Covid-19 are expected to present a novelty and benefit for the realization of effective and efficient education. In carrying out technology-based online learning, teachers, students, and parents have experience as well as new knowledge related to learning technology, especially 
for those who are technology stuttering. The hope is that learning innovations during the Covid-19 pandemic can be used as an opportunity to support the quality of education in the future and be able to compete globally.

\section{References}

Al-Tabany, T. I. B. (2017). Mendesain model pembelajaran inovatif, progresif, dan konstektual: konsep, landasan, dan implementasinya pada kurikulum 2013 (Kurikulum Tematik Integratif/KTI) (3rd ed). Jakarta: Kencana.

Anggara, S. (2015). Metode penelitian administratif. Bandung: Pustaka Setia.

Arikunto, S. (2016). Manajemen penelitian. Jakarta: Rineka Cipta.

Ariyandi, N. (2020). Ngobrol publik 2020 klaster education teknologi. Konten Adalah Koentji: Jurus Guru Zaman Now Mahir Konten Digital [Webinar]. PIBo. https://www.youtube.com/watch?v=w TcAfn2BBAY.

Atsani, K. L. G. M. Z. (2020). Transformasi media pembelajaran pada masa Pandemi COVID-19. AlHikmah: Jurnal Studi Islam, 1(1), 82- 93.

Chaeruman, U. A. (2017). PEDATI model desain sistem pembelajaran Blended. Panduan Merancang Mata Kuliah Daring SPADA Indonesia.

Darmalaksana, W. (2020). Corona hadis. Fakultas Ushuluddin UIN Sunan Gunung Djati Bandung.

Haerudin, Cahyani, A., Sitihanifah, N., Setiani, R. N., Nurhayati, S., Oktaviana, V., \& Sitorus, Y. I. (2020). Peran orangtua dalam membimbing anak selama pembelajaran di rumah sebagai upaya memutus Covid-19. Universitas Singaperbangsa Karawang, 3(1), 1-12.

He, W., Xu, G., \& Kruck, S. E. (2014). Online IS education for the 21st century. Journal of Information Systems Education, 25(2), 101-106.

Huda, M., et al. (2018). Understanding Modern Learning Environment (MLE) in big data era. International Journal of Emerging Technologies in Learning (iJET), 13(05), 71-85.

Istiningsih. (2020). Learning innovation in the pandemic period Covid-19 [Webinar]. UIN Sunan Kalijaga Yogyakarta.

Kadi, T., \& Awwaliyah, R. (2017). Inovasi pendidikan: Upaya penyelesaian problematika pendidikan di Indonesia. Jurnal Islam Nusantara, 1(2).

Kemendikbud. (2020a). Bersama hadapi corona. Jakarta, Indonesia: Kemendikbud.

Kemendikbud. (2020b). Pedoman penyelenggaraan belajar dari rumah. Jakarta: Kemendikbud.

Putri, G.S. (2020). WHO resmi sebut virus corona Covid-19 sebagai pandemi. Kompas. Retrieved from https://www.kompas.com/sains/read/2020/03/12/083129823/who-resmisebut-virus-corona-covid19-sebagaipandemi-global?page $=$ all 
Purnamasari, D. M. (2020). Update 17 Juni: Pasien Covid-19 Meninggal Capai 2.276 Orang. Kompas Nasional. Retrieved from https://nasional.kompas.com/read/202 0/06/17/15592881/update-17junipasien-covid-19-meninggal-duniacapai-2276-orang.

Kusnandi, K. (2019). Model inovasi pendidikan dengan strategi implementasi konsep "Dare to Be Different”. Jurnal Wahana Pendidikan, 4(1), 132-144.

Melhuish, E. C., Phan, M. B., Sylva, K., Sammons, P., Siraj-Blatchford, I., \& Taggart, B. (2008). Effects of the home learning environment and preschool center experience upon literacy and numeracy development in early primary school. Journal of Social Issues, 64(1), 95-114.

Mendikbud. (2020). Surat Edaran Menteri Pendidikan Dan Kebudayaan Nomor 4 Taun 2020 Tentang Pelaksanaan Kebijakan Pendidikan Selama Masa Darurat Penyebaran Coronavirus Desease (Covid-19). Jakarta, Indonesia: Mendikbud.

Mendikbud. (2013). Peraturan Kementerian Pendidikan Dan Kebudayaan Nomor 65 Tahun 2013 Tentang Standar Proses Pendidikan Dasar dan Menengah. Jakarta, Indonesia: Mendikbud.

Miarso, Y. (2007). Menyemai benih teknologi pendidikan. Jakarta: Prenadamedia Group.

Nawangsari, D. (2010). Urgensi inovasi dalam sistem pendidikan. Jurnal Falasifa, 1(1).

Panigrahi, R., Srivastava, P. R., \& Sharma, D. (2018). Online learning: Adoption, continuance, and learning outcome - A review of the literature. International Journal of Information Management, $43,1-14$.

Rina, D. (2020). Pencegahan penyebaran virus corona di bandara menggunakan artificial intellegence. STRING (Satuan Tulisan Riset dan Inovasi Teknologi), 5(1), 94-100.

Sadikin, A., \& Hamidah, A. (2020). Pembelajaran daring di tengah wabah Covid-19: Online Learning in the Middle of the Covid-19 Pandemic. Biodik, 6(2), 214-224.

Sanjaya, W. (2006). Strategi pembelajaran. Al-Tarbiyah, 30(2), 111-123.

Shi, H., et al. (2020). Radiological findings from 81 patients with COVID-19 pneumonia in Wuhan, China: a descriptive study. The Lancet Summit, 20(4), 425-343.

Sudarsana, I. K., et al. (2020). Covid-19: Perspektif Pendidikan. Jakarta: Yayasan Kita Menulis

Sururi, A. (2017). Inovasi kebijakan dalam perspektif administrasi publik menuju terwujudnya good public policy governance. Spirit Publik: Jurnal Administrasi Publik, 12(2), 14-31.

Syarifudin, A. S. (2020). Impelementasi pembelajaran daring untuk meningkatkan mutu pendidikan sebagai dampak diterapkannya social distancing. Jurnal Pendidikan Bahasa dan Sastra Indonesia Metalingua, 5(1), 31-34. 
Valeza, A. R. (2017). "Peran orang tua dalam meningkatkan prestasi anak di Perum Tanjung Raya Permai Kelurahan Pematang Wangi Kecamatan Tanjung Senang Bandar Lampung.” Doctoral dissertation, UIN Raden Intan Lampung.

Widaningsih, I. (2019). Strategi dan inovasi pembelajaran bahasa Indonesia di Era Revolusi Industri 4.0. Uwais Inspirasi Indonesia.

Winingsih, E. (2020). Peran orang tua dalam pembelajaran jarak jauh. Poskita. https://poskita. co/2020/04/02/peranorangtua-dalampembelajaran-jarakjauh.

Yanti, F. A., Mundilarto, M. P., \& Kuswanto, H. (2019). Teori dan aplikasi model cooperative research Project Based Learning di Perguruan Tinggi. Yogyakrta: Gre Publishing.

Yaumi, M. (2018). Media dan teknologi pembelajaran. Jakarta. Prenadamedia Group. 